\title{
Studi Mobile Commerce Di Bandar Lampung
}

\author{
${ }^{1}$ Tristiyanto, ${ }^{2}$ Syintia Dwi Nurrahmi, \& ${ }^{3}$ Yunda Heningtyas
}

\author{
1,2,3 Jurusan Ilmu Komputer FMIPA, Universitas Lampung, \\ J1. Prof. Dr. Ir. Sumantri Brojonegoro No.1 Bandar Lampung, Lampung, Indonesia \\ e-mail: ${ }^{1}$ tristiyanto.1981@fmipa.unila.ac.id, ${ }^{2}$ syintia.dwi1140@students.unila.ac.id
}

\begin{abstract}
The online shopping process in Bandar Lampung is facilitating by mobile commerce online shopping. The factor of using online shopping mobile commerce has never been analyzed based on the public perception in Bandar Lampung. This research discusses using mobile-commerce online shopping using the UTAUT2 model with Perceived Risk manifestations, namely Security Risk and Privacy Risk. The mobile commerce applications analyzed were Shopee, Lazada, Tokopedia, Bukalapak, and Blibli. The purpose of this research was to determine the UTAUT2 variable with the manifestation of Perceived Risk, namely Security Risk and Privacy Risk, which affect the use of online shopping mobile commerce. The data analysis method used is Structural Equation Modeling (SEM) with Partial Least Square (PLS) approach. The total number of respondents obtained was 183 respondents. The data tested were 373 data. This research results from the factors that most influence the behavioral intention and use behavior of mobile commerce online shopping is a habit.
\end{abstract}

Keywords: Manifest Perceived Risk; Mobile Commerce; Online Shopping; Partial Least Square; Structural Equation Modeling; UTAUT2

\section{PENDAHULUAN}

Seiring berjalannya waktu, perkembangan dunia teknologi informasi saat ini sudah menyentuh seluruh aspek kehidupan manusia dari sektor pertanian, kesehatan, pendidikan, transportasi dan juga sektor perdagangan. Khusus sektor perdagangan, para pebisnis skala kecil maupun besar berlomba-lomba untuk mendapatkan pembeli atas produk yang dipasarkan. Kebutuhan akan proses jual beli yang sangat cepat ini memaksa mereka untuk menerapkan trend saat ini yaitu strategi pemasaran produk secara online.

Perdagangan elektronik (e-commerce $=$ electronic commerce) adalah bagian dari e-lifestyle yang memungkinkan transaksi jual beli dilakukan secara online dari sudut tempat mana pun[1]. E-Commerce yang dapat diakses dalam bentuk mobile dikenal dengan istilah Mobile Commerce (m-commerce). Ketika $e$ commerce dilakukan dalam lingkungan nirkabel, seperti dengan menggunakan telepon seluler untuk mengakses internet dan berbelanja, maka hal ini disebut $m$-commerce [2].

Mobile Commerce atau yang lebih di kenal dengan M-Commerce merupakan sebuah fenomena yang cukup baru pada abad ke 21 yang di bangun dari generasi sebelumnya yaitu Electronic Commerce atau ECommerce. Perusahaan mulai mengaplikasikan program Mobile Commerce dikarenakan oleh banyaknya masyarakat yang sudah aktif menggunakan ponsel dan sudah tidak asing lagi dengan internet [3].

Berdasarkan survei dari Asosiasi Penyelenggara Jasa Internet Indonesia (APJII) pada tahun 2018 sudah ada 171,17 juta jiwa $(64,8 \%)$ pengguna aktif internet dari total populasi 264,16 juta jiwa penduduk Indonesia[4]. Berbeda dengan dua tahun sebelumnya, pada tahun 2017 hanya 143,26 juta jiwa (54,86\%) pengguna internet aktif di Indonesia dari total populasi 262 juta jiwa penduduk Indonesia[5]. Sedangkan pada tahun 2016 hanya sebesar 132,7 juta jiwa pengguna internet aktif di Indonesia dari total populasi 256,2 juta jiwa penduduk Indonesia[6]. Jumlah pengguna internet aktif tersebut diperkirakan akan bertambah setiap tahunnya. $\mathrm{P}$ eningkatan jumlah pengguna internet aktif yang besar tersebut, berbanding lurus dengan jumlah akses e-commerce dalam belanja online [5]. Berdasarkan data survei APJII 2018 bahwa Lampung memiliki kontribusi besar kelima sebagai pengguna internet aktif di Indonesia[4] dan survei APJII 2017 yang 
menyatakan bahwa jumlah pengguna aktif internet berbanding lurus dengan jumlah akses e-commerce[5], maka perlu dilakukan penelitian yang berhubungan dengan $e$-commerce yaitu $m$-commerce belanja online dan penelitian tersebut dilakukan di salah satu Kota yang ada di Lampung yaitu Bandar Lampung.

Layanan m-commerce belanja online Indonesia sudah banyak dikenal di wilayah Bandar Lampung seperti Shopee, Lazada, Bukalapak, Tokopedia, dan lainnya. Namun, belum ada penelitian tentang aplikasi $m$ commerce yang paling sering digunakan di Bandar Lampung dan faktor-faktor yang mempengaruhi penggunaan aplikasi m-commerce yang ada di Indonesia. Oleh sebab itu, penelitian ini menggunakan beberapa aplikasi $m$-commerce dari Peta e-commerce Indonesia data kuartal 4 tahun 2019 yaitu Shopee, Lazada, Bukalapak, Tokopedia, dan Blibli untuk dilakukan penelitian[7]. Peta e-commerce Indonesia merupakan peta yang mengurutkan pemain besar e-commerce berdasarkan rata-rata pengunjung website di setiap kuartal, ranking aplikasi, pengikut media sosial, dan jumlah karyawan[7].

Adanya aplikasi m-commerce adalah bukti dari semakin majunya teknologi dalam sektor perdagangan elektronik. Teknologi yang semakin maju ini perlu dilakukan peninjauan dari sisi pengguna aplikasi $m$ commerce dalam berbagai aspek seperti : Performance Expectacy, Effort Expetancy, Sosial Influence, Facilitating Condition, Hedonic Motivation, Price Value, dan Habit. Aspek-aspek tersebut untuk mengetahui apakah berpengaruh terhadap Behavioral Intention to Use the System. Selanjutnya peninjauan aspek manifestasi dari sisi Perceived Risk yaitu Privacy Risk) dan Security Risk. Penambahan dua manifestasi tersebut dalam mengidentifikasi pemanfaatan m-commerce di Bandar Lampung untuk mengetahui apakah aspek tersebut juga berpengaruh terhadap niat dan perilaku penggunaan teknologi (Behavioral Intention to Use the System). Untuk itu, pendekatan Unified Theory of Acceptance and Use of Technology 2 (UTAUT2) dan manifestasi Perceived Risk dalam penelitian ini diterapkan untuk mengidentifikasi pemanfaatan $m$ commerce di Bandar Lampung.

\section{METODOLOGI PENELITIAN}

\subsection{Model Penelitian}

Penelitian ini menggunakan model kerangka berpikir teoritis yaitu UTAUT2 dan manifestasi Perceived Risk yaitu Privacy Risk dan Security Risk. Model tersebut digunakan untuk menganalisis faktor penggunaan mobile commerce belanja online di Kota Bandar Lampung. Sesuai dengan lingkup penelitian, maka model yang digunakan seperti pada Gambar 1.

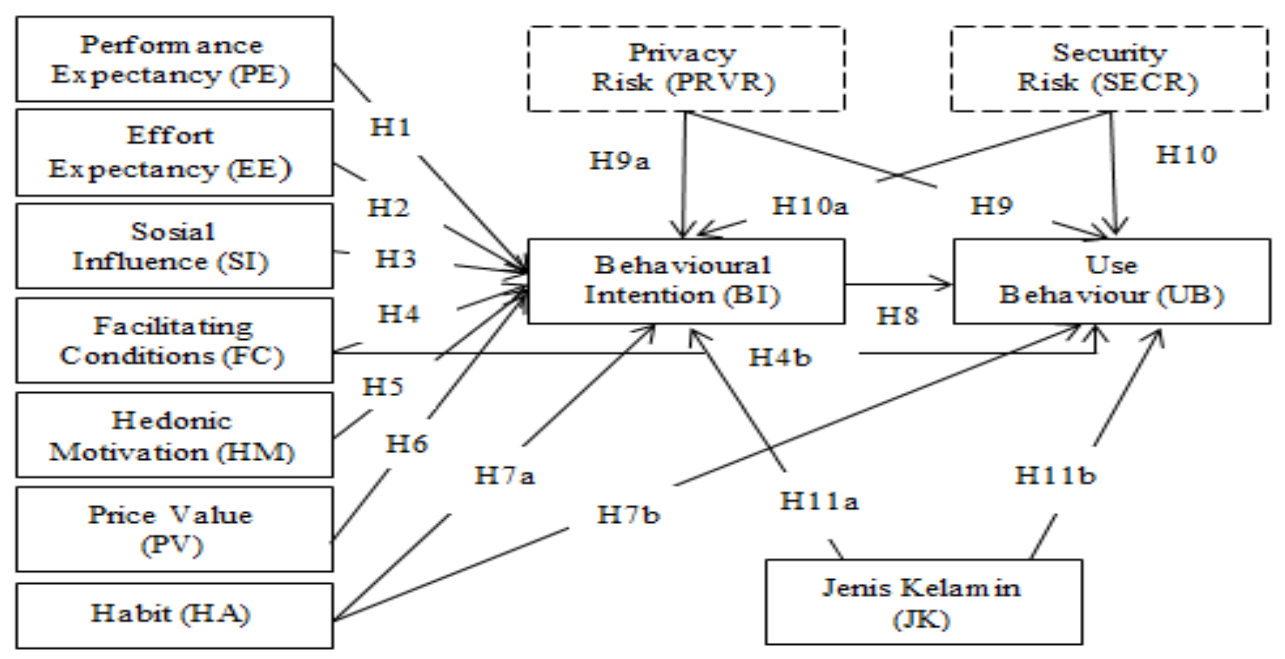

Keterangan :

$\longrightarrow$ UTAUT2 [8]

- - Manifestasi Perceived Risk [9] 
Berdasarkan model penelitian pada Gambar 1, maka penelitian ini bertujuan untuk mengetahui hubungan antara variabel-variabel tersebut antara lain :

1. Untuk mengetahui faktor-faktor apa saja yang mempengaruhi penerimaan dan penggunaan $m$-commerce belanja online di Bandar Lampung menggunakan model UTAUT2.

2. Untuk mengetahui apakah penambahan dua aspek privacy risk dan security risk berpengaruh dalam penerimaan dan penggunaan m-commerce belanja online di Bandar Lampung.

\subsection{Hipotesis Penelitian}

Berdasarkan model penelitian, maka diajukan hipotesis tentang hubungan antara konstruk-konstruk independen yang terdiri dari konstruk PE (performance expectancy), konstruk EE (effort expectancy), konstruk SI (social influence), konstruk FC (facilitating condition), konstruk HM (hedonic motivation), konstruk PV (price value), konstruk HA (habit), konstruk PRVR (privacy risk) dan konstruk SECR (security risk) terhadap konstruk dependen yaitu Behavioural Intention (BI). Selanjutnya, hubungan antara konstruk FC (facilitating condition), konstruk HA (habit), konstruk PRVR (privacy risk) dan konstruk SECR (security risk) terhadap konstruk dependen Use Behaviour (UB) mobile commerce belanja online. Hipotesis yang diajukan dalam penelitian ini dapat dilihat pada Tabel 1.

Tabel 1. Hipotesis Penelitian

\begin{tabular}{|c|c|}
\hline \multicolumn{2}{|r|}{ Hipotesis } \\
\hline H1 & $\begin{array}{l}\text { Terdapat hubungan ekspektasi kinerja (performance expectancy) dengan niat } \\
\text { perilaku (behavioural intention). }\end{array}$ \\
\hline $\mathbf{H} 2$ & $\begin{array}{l}\text { Terdapat hubungan ekspektasi upaya (effort expectancy) dengan niat perilaku } \\
\text { (behavioural intention). }\end{array}$ \\
\hline H3 & $\begin{array}{l}\text { Terdapat hubungan pengaruh sosial (social influence) dengan niat perilaku } \\
\text { (behavioural intention). }\end{array}$ \\
\hline H4a & $\begin{array}{l}\text { Terdapat hubungan kondisi-kondisi pemfasilitasi (facilitating condition) dengan } \\
\text { niat perilaku (behavioural intention). }\end{array}$ \\
\hline H4b & $\begin{array}{l}\text { Terdapat hubungan kondisi-kondisi pemfasilitasi (facilitating conditions) dengan } \\
\text { perilaku penggunaan (use behaviour). }\end{array}$ \\
\hline H5 & $\begin{array}{l}\text { Terdapat hubungan motivasi kesenangan (hedonic motivation) dengan niat } \\
\text { perilaku (behavioural intention). }\end{array}$ \\
\hline H6 & $\begin{array}{l}\text { Terdapat hubungan nilai harga (price value) dengan niat perilaku (behavioural } \\
\text { intention). }\end{array}$ \\
\hline $\mathbf{H 7 a}$ & $\begin{array}{l}\text { Terdapat hubungan kebiasaan (habit) dengan niat perilaku (behavioural } \\
\text { intention). }\end{array}$ \\
\hline H7b & $\begin{array}{l}\text { Terdapat hubungan kebiasaan (habit) dengan perilaku penggunaan (use } \\
\text { behaviour). }\end{array}$ \\
\hline H8 & $\begin{array}{l}\text { Terdapat hubungan niat perilaku (behavioural intention) dengan perilaku } \\
\text { penggunaan (use behaviour). }\end{array}$ \\
\hline H9a & $\begin{array}{l}\text { Terdapat hubungan resiko privasi (privacy risk) dengan niat perilaku (behavioural } \\
\text { intention). }\end{array}$ \\
\hline H9b & $\begin{array}{l}\text { Terdapat hubungan risiko privasi (privacy risk) dengan perilaku penggunaan (use } \\
\text { behaviour). }\end{array}$ \\
\hline H10a & $\begin{array}{l}\text { Terdapat hubungan risiko keamanan (security risk) dengan niat perilaku } \\
\text { (behavioural intention). }\end{array}$ \\
\hline H10b & $\begin{array}{l}\text { Terdapat hubungan risiko keamanan (security risk) dengan perilaku penggunaan } \\
\text { (use behaviour). }\end{array}$ \\
\hline H11a & $\begin{array}{l}\text { Terdapat hubungan jenis kelamin (gender) dengan niat perilaku (behavioural } \\
\text { intention). }\end{array}$ \\
\hline H11b & $\begin{array}{l}\text { Terdapat hubungan jenis kelamin (gender) dengan perilaku penggunaan (use } \\
\text { behaviour). }\end{array}$ \\
\hline
\end{tabular}


(C)2021 Ilmu Komputer Unila Publishing Network all rights reserved

\subsection{Data Penelitian}

Dalam penelitian ini, data yang digunakan untuk analisis faktor penggunaan $m$-commerce yaitu toko online yang memiliki aplikasi mobile commerce di PlayStore dan AppStore berdasarkan Peta E-commerce Indonesia. Diambil lima peringkat tertinggi berdasarkan rangking PlayStore dan rangking AppStore. Lima peringkat tertinggi pada PlayStore dan AppStore meliputi Shopee, Lazada, Tokopedia, Bukalapak, dan Blibli.

Data responden diperoleh dari pengisian kuesioner yang disebar di Bandar Lampung. Dalam kuesioner tersebut, satu responden harus mengisi setiap aplikasi m-commerce berdasarkan pengalaman penggunaan. Data yang digunakan dalam penelitian ini hanya 183 responden, dengan rincian 373 data dari pengguna $\mathrm{m}$ commerce. Selanjutnya, dalam pengisian kuesioner terdapat karakteristik responden yaitu jenis kelamin. Data karakteristik responden yang diperoleh yaitu laki-laki sebanyak 95 responden dan perempuan sebanyak 88 responden.

\subsection{Metode Analisis Data}

Metode analisis data yang digunakan pada penelitian ini yaitu Structural Equation Model (SEM) menggunakan pendekatan Partial Least Square (PLS) dan SmartPLS versi 3.2.9 sebagai software-nya. Evaluasi model PLS dilakukan dengan mengevaluasi model pengukuran (outer model) dan model struktural (inner model).

\section{HASIL DAN PEMBAHASAN}

\subsection{Pengujian Model Pengukuran (Outer Model)}

\subsubsection{Uji Validitas Konstruk}

Uji Validitas Konstruk pada penelitian ini terdiri dari uji validitas konvergen dan uji validitas diskriminan.

\section{Uji Validitas Konvergen}

Berikut pada Tabel 2. merupakan nilai outer loading dari aplikasi Shopee, Lazada, Tokopedia, Bukalapak, dan Blibli.

Tabel 2. Nilai Outer Loading

\begin{tabular}{|c|c|c|c|c|c|c|c|c|c|c|c|}
\hline \multirow{3}{*}{ Variabel } & \multirow{3}{*}{ Indikator } & \multicolumn{10}{|c|}{ Nilai Outer Loading } \\
\hline & & \multicolumn{2}{|c|}{ Shopee } & \multicolumn{2}{|c|}{ Lazada } & \multicolumn{2}{|c|}{ Tolkopedia } & \multicolumn{2}{|c|}{ Bukalapak } & \multicolumn{2}{|c|}{ Blibli } \\
\hline & & $\begin{array}{l}\text { Hitung } \\
\text { ke- } 1\end{array}$ & $\begin{array}{l}\text { Hitung } \\
\text { ke-2 }\end{array}$ & $\begin{array}{l}\text { Hitung } \\
\text { ke- } 1\end{array}$ & $\begin{array}{l}\text { Hitung } \\
\text { ke-2 }\end{array}$ & $\begin{array}{l}\text { Hitung } \\
\text { ke- } 1\end{array}$ & $\begin{array}{l}\text { Hitung } \\
\text { ke-2 }\end{array}$ & $\begin{array}{l}\text { Hitung } \\
\text { ke- } 1\end{array}$ & $\begin{array}{l}\text { Hitung } \\
\text { ke-2 }\end{array}$ & $\begin{array}{l}\text { Hitung } \\
\text { ke- } 1\end{array}$ & $\begin{array}{l}\text { Hitung } \\
\text { ke-2 }\end{array}$ \\
\hline \multirow{3}{*}{$\begin{array}{l}\text { Performance } \\
\text { Expectancy } \\
\text { (PE) }\end{array}$} & PE1 & 0.878 & 0.878 & 0.858 & 0.858 & 0.775 & 0.775 & 0.869 & 0.869 & 0.869 & 0.869 \\
\hline & PE2 & 0.777 & 0.777 & 0.838 & 0.838 & 0.711 & 0.712 & 0.906 & 0.906 & 0.912 & 0.912 \\
\hline & PE3 & 0.849 & 0.849 & 0.934 & 0.934 & 0.975 & 0.975 & 0.758 & 0.758 & 0.850 & 0.850 \\
\hline \multirow{4}{*}{$\begin{array}{c}\text { Effort } \\
\text { Expectancy } \\
\text { (EE) }\end{array}$} & EEl & 0.903 & 0.919 & 0.849 & 0.849 & 0.560 & 0.998 & 0.917 & 0.922 & 0.893 & 0.907 \\
\hline & $\mathrm{EE} 2$ & 0.889 & 0.936 & 0.844 & 0.844 & 0.965 & 0.789 & 0.935 & 0.960 & 0.888 & 0.936 \\
\hline & $\mathrm{EE} 3$ & 0.659 & dihspus & 0.845 & 0.845 & 0.774 & 0.888 & 0.580 & dihspus & 0.299 & dihspus \\
\hline & $\mathrm{EE} 4$ & 0.864 & 0.915 & 0.832 & 0.832 & 0.627 & dihspus & 0.897 & 0.927 & 0.905 & 0.917 \\
\hline \multirow{4}{*}{$\begin{array}{l}\text { Sosial } \\
\text { Influence } \\
\text { (SI) }\end{array}$} & SIl & 0.860 & 0.860 & 0.830 & 0.830 & 0.852 & 0.892 & 0.846 & 0.846 & 0.797 & 0.797 \\
\hline & $\mathrm{SI} 2$ & 0.915 & 0.915 & 0.910 & 0.910 & 0.886 & 0.819 & 0.937 & 0.937 & 0.882 & 0.882 \\
\hline & SI3 & 0.779 & 0.779 & 0.856 & 0.856 & 0.873 & 0.892 & 0.754 & 0.754 & 0.757 & 0.757 \\
\hline & SI4 & 0.821 & 0.821 & 0.815 & 0.815 & 0.639 & dihspus & 0.827 & 0.828 & 0.834 & 0.834 \\
\hline \multirow{3}{*}{$\begin{array}{c}\text { Facilitating } \\
\text { Conditions } \\
\text { (FC) }\end{array}$} & $\mathrm{FCl}$ & 0.887 & 0.887 & 0.784 & 0.784 & 0.647 & dihspus & 0.912 & 0.912 & 0.842 & 0.842 \\
\hline & $\mathrm{FC} 2$ & 0.805 & 0.805 & 0.772 & 0.772 & 0.727 & 0.892 & 0.824 & 0.824 & 0.870 & 0.870 \\
\hline & $\mathrm{FC}_{3}$ & 0.907 & 0.907 & 0.878 & 0.878 & 0.869 & 0.819 & 0.935 & 0.935 & 0.860 & 0.860 \\
\hline \multirow{3}{*}{$\begin{array}{l}\text { Hedonic } \\
\text { Motruation } \\
\text { (HM) }\end{array}$} & HMl & 0.901 & 0.901 & 0.756 & 0.871 & 0.666 & dihspus & 0.957 & 0.957 & 0.753 & 0.753 \\
\hline & $\mathrm{HM} 2$ & 0.904 & 0.904 & 0.649 & dihspus & 0.823 & 0.881 & 0.950 & 0.950 & 0.908 & 0.908 \\
\hline & HM13 & 0.920 & 0.920 & 0.853 & 0.810 & 0.806 & 0.873 & 0.964 & 0.964 & 0.844 & 0.844 \\
\hline \multirow{3}{*}{$\begin{array}{l}\text { Price Value } \\
\text { (PV) }\end{array}$} & PV1 & 0.841 & 0.841 & 0.886 & 0.886 & 0.722 & 0.722 & 0.920 & 0.920 & 0.648 & dihspus \\
\hline & pv2 & 0.936 & 0.936 & 0.954 & 0.954 & 0.942 & 0.942 & 0.929 & 0.929 & 0.860 & 0.951 \\
\hline & PV3 & 0.942 & 0.942 & 0.983 & 0.983 & 0.899 & 0.899 & 0.922 & 0.922 & 0.933 & 0.929 \\
\hline
\end{tabular}


C2021 Ilmu Komputer Unila Publishing Network all rights reserved

\begin{tabular}{|c|c|c|c|c|c|c|c|c|c|c|c|}
\hline \multirow{3}{*}{$\begin{array}{l}\text { Habit } \\
\text { (HA) }\end{array}$} & HAl & 0.911 & 0.911 & 0.860 & 0.860 & 0.762 & 0.762 & 0.917 & 0.917 & 0.933 & 0.933 \\
\hline & HA2 & 0.938 & 0.938 & 0.962 & 0.962 & 0.915 & 0.915 & 0.940 & 0.940 & 0.935 & 0.935 \\
\hline & $\mathrm{HA}_{3}$ & 0.925 & 0.925 & 0.895 & 0.895 & 0.885 & 0.885 & 0.943 & 0.943 & 0.948 & 0.948 \\
\hline \multirow{3}{*}{$\begin{array}{l}\text { Privacy Risk } \\
\text { (PRVR) }\end{array}$} & PRVR1 & 0.669 & dihapus & 0.412 & dihspus & 0.947 & 0.948 & 0.805 & 0.805 & 0.870 & 0.870 \\
\hline & PRVR2 & 0.967 & 1.000 & 0.997 & 1.000 & 0.736 & 0.736 & 0.932 & 0.932 & 0.906 & 0.906 \\
\hline & PRVR 3 & 0.583 & dihspus & 0.260 & dihspus & 0.846 & 0.846 & 0.814 & 0.814 & 0.737 & 0.737 \\
\hline \multirow{3}{*}{$\begin{array}{l}\text { Security Risk } \\
\text { (SECR) }\end{array}$} & SECRI & 0.844 & 0.839 & 0.876 & 0.885 & 0.902 & 0.902 & 0.899 & 0.899 & 0.852 & 0.860 \\
\hline & SECR2 & 0.600 & dihapus & 0.661 & dihspus & 0.730 & 0.730 & 0.855 & 0.855 & 0.488 & dihspus \\
\hline & SECR 3 & 0.914 & 0.924 & 0.823 & 0.890 & 0.921 & 0.921 & 0.873 & 0.873 & 0.901 & 0.896 \\
\hline \multirow{3}{*}{$\begin{array}{l}\text { Behavioural } \\
\text { Intention } \\
\text { (BI) }\end{array}$} & BIl & 0.932 & 0.932 & 0.909 & 0.908 & 0.958 & 0.958 & 0.934 & 0.934 & 0.925 & 0.925 \\
\hline & $\mathrm{BI} 2$ & 0.921 & 0.921 & 0.836 & 0.837 & 0.911 & 0.911 & 0.957 & 0.957 & 0.928 & 0.928 \\
\hline & $\mathrm{BI} 3$ & 0.917 & 0.917 & 0.910 & 0.910 & 0.947 & 0.947 & 0.927 & 0.927 & 0.934 & 0.934 \\
\hline \multirow{3}{*}{$\begin{array}{c}\text { Use } \\
\text { Behaviour } \\
\text { (UB) }\end{array}$} & UB1 & 0.935 & 0.935 & 0.889 & 0.888 & 0.959 & 0.959 & 0.949 & 0.949 & 0.939 & 0.939 \\
\hline & UB2 & 0.817 & 0.817 & 0.903 & 0.903 & 0.942 & 0.941 & 0.774 & 0.774 & 0.751 & 0.751 \\
\hline & UB3 & 0.956 & 0.956 & 0.918 & 0.918 & 0.912 & 0.913 & 0.957 & 0.957 & 0.956 & 0.956 \\
\hline Jenis & UB4 & 0.892 & 0.892 & 0.887 & 0.887 & 0.964 & 0.964 & 0.898 & 0.898 & 0.907 & 0.907 \\
\hline $\begin{array}{c}\text { Kelamin } \\
\text { (JK) }\end{array}$ & GENDER & 1.000 & 1.000 & 1.000 & 1.000 & 1.000 & 1.000 & 1.000 & 1.000 & 1.000 & 1.000 \\
\hline
\end{tabular}

(Sumber: Hasil Pengolahan SmartPLS 3.2.9, 2020)

Nilai outer loading dilihat berdasarkan hasil hitung ke-2. Pada hitung ke-2, indikator yang tidak valid sudah di hapuskan. Nilai outer loading masing-masing aplikasi sudah memenuhi (rule of thumbs > 0,7)[10]. Penghapusan indikator dilakukan, supaya skor AVE dan communality tidak dibawah (rule of thumbs > 0,5)[10]. Uji validitas konvergen selanjutnya yaitu menghitung nilai AVE dan communality. Nilai AVE dan communality dapat dilihat pada Tabel 3.

Tabel 3. Nilai AVE dan Communality

\begin{tabular}{|c|c|c|c|c|c|c|c|c|c|c|}
\hline \multirow{3}{*}{ Variabel } & \multicolumn{10}{|c|}{ Nilai AVE dan Communality } \\
\hline & \multicolumn{2}{|c|}{ Shopee } & \multicolumn{2}{|c|}{ Lazada } & \multicolumn{2}{|c|}{ Tokopedia } & \multicolumn{2}{|c|}{ Bukalapak } & \multicolumn{2}{|c|}{ Blibli } \\
\hline & AVE & $\begin{array}{c}\text { Commu- } \\
\text { nality }\end{array}$ & AVE & $\begin{array}{l}\text { Commul- } \\
\text { Nality }\end{array}$ & AVE & $\begin{array}{l}\text { Compul- } \\
\text { Nality }\end{array}$ & AVE & $\begin{array}{l}\text { Compul- } \\
\text { nality }\end{array}$ & AVE & $\begin{array}{l}\text { Compul- } \\
\text { nality }\end{array}$ \\
\hline $\begin{array}{l}\text { Performance } \\
\text { Expectancy } \\
\text { (PE) }\end{array}$ & 0.698 & 0.698 & 0.770 & 0.770 & 0.686 & 0.686 & 0.717 & 0.717 & 0.769 & 0.769 \\
\hline $\begin{array}{c}\text { Effort } \\
\text { Expectancy } \\
\text { (EE) }\end{array}$ & 0.853 & 0.853 & 0.710 & 0.710 & 0.809 & 0.809 & 0.876 & 0.876 & 0.846 & 0.846 \\
\hline $\begin{array}{c}\text { Sosial } \\
\text { Imfluence (SI) }\end{array}$ & 0.714 & 0.714 & 0.729 & 0.729 & 0.782 & 0.782 & 0.712 & 0.712 & 0.671 & 0.671 \\
\hline $\begin{array}{l}\text { Facilitating } \\
\text { Conditions } \\
\text { (FC) }\end{array}$ & 0.753 & 0.753 & 0.660 & 0.660 & 0.733 & 0.733 & 0.795 & 0.795 & 0.735 & 0.735 \\
\hline $\begin{array}{c}\text { Hedonic } \\
\text { Motivation } \\
\text { (HM) }\end{array}$ & 0.825 & 0.825 & 0.708 & 0.708 & 0.769 & 0.769 & 0.916 & 0.916 & 0.701 & 0.701 \\
\hline $\begin{array}{l}\text { Price Value } \\
\text { (PV) }\end{array}$ & 0.823 & 0.823 & 0.887 & 0.887 & 0.739 & 0.739 & 0.853 & 0.853 & 0.884 & 0.884 \\
\hline $\begin{array}{c}\text { Habit } \\
\text { (HA) }\end{array}$ & 0.855 & 0.855 & 0.822 & 0.822 & 0.734 & 0.734 & 0.872 & 0.872 & 0.881 & 0.881 \\
\hline $\begin{array}{l}\text { Privacy Risk } \\
\text { (PRVR) }\end{array}$ & 1.000 & 1.000 & 1.000 & 1.000 & 0.718 & 0.718 & 0.727 & 0.727 & 0.706 & 0.706 \\
\hline $\begin{array}{l}\text { Security Risk } \\
\text { (SECR) }\end{array}$ & 0.779 & 0.779 & 0.788 & 0.788 & 0.731 & 0.731 & 0.767 & 0.767 & 0.771 & 0.771 \\
\hline $\begin{array}{l}\text { Behanioural } \\
\text { Intention (BI) }\end{array}$ & 0.852 & 0.852 & 0.784 & 0.784 & 0.881 & 0.881 & 0.883 & 0.883 & 0.863 & 0.863 \\
\hline $\begin{array}{c}\text { Use } \\
\text { Behaviour } \\
\text { (UB) }\end{array}$ & 0.813 & 0.813 & 0.808 & 0.808 & 0.892 & 0.892 & 0.806 & 0.806 & 0.795 & 0.795 \\
\hline $\begin{array}{c}\text { Jenis } \\
\text { Kelamin } \\
\text { (JK) }\end{array}$ & 1.000 & 1.000 & 1.000 & 1.000 & 1.000 & 1.000 & 1.000 & 1.000 & 1.000 & 1.000 \\
\hline
\end{tabular}

(Sumber: Hasil Pengolahan SmartPLS 3.2.9, 2020) 
Berdasarkan hasil hitung ke-2, nilai AVE dan Communality masing-masing aplikasi sudah memenuhi (rule of thumbs $>0,5)[10]$.

\section{Uji Validitas Diskriminan}

Uji validitas diskriminan melihat skor cross loading dengan ketentuan masing-masing indikator disuatu konstruk harus berbeda dengan indikator di konstruk lain[10]. Perbedaan tersebut dilihat dari nilai indikator disuatu konstruk harus lebih tinggi daripada indikator di konstruk lain [10]. Berikut pada Tabel 4. merupakan salah satu hasil Cross Loading dari aplikasi m-commerce Shopee.

Tabel 4. Nilai Cross Loading Shopee

\begin{tabular}{|c|c|c|c|c|c|c|c|c|c|c|c|c|}
\hline Variabel & 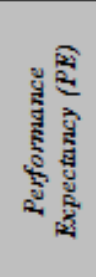 & 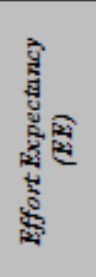 & 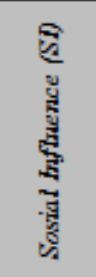 & 悬 & 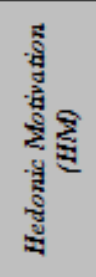 & 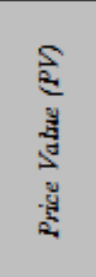 & 氙 & 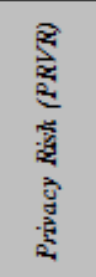 & 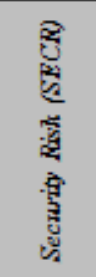 & 霄 & 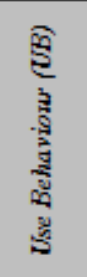 & 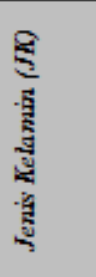 \\
\hline PEI & 0.878 & 0.675 & 0.559 & 0.648 & 0.707 & 0.676 & 0.495 & 0.250 & 0.169 & 0.472 & 0.600 & -0.064 \\
\hline PE2 & 0.777 & 0.727 & 0.403 & 0.575 & 0.665 & 0.556 & 0.425 & 0.206 & 0.122 & 0.351 & 0.576 & -0.090 \\
\hline PE3 & 0.849 & 0.467 & 0.605 & 0.495 & 0.604 & 0.662 & 0.475 & 0.190 & 0.109 & 0.515 & 0.494 & -0.075 \\
\hline $\mathrm{EE} 1$ & 0.694 & 0.919 & 0.482 & 0.596 & 0.730 & 0.614 & 0.474 & 0.251 & 0.057 & 0.406 & 0.606 & -0.096 \\
\hline EE2 & 0.639 & 0.936 & 0.509 & 0.623 & 0.811 & 0.632 & 0.525 & 0.282 & 0.048 & 0.386 & 0.635 & -0.166 \\
\hline EE4 & 0.670 & 0.915 & 0.532 & 0.753 & 0.770 & 0.685 & 0.572 & 0.296 & 0.158 & 0.530 & 0.708 & -0.085 \\
\hline SIl & 0.432 & 0.391 & 0.860 & 0.464 & 0.512 & 0.620 & 0.540 & 0.307 & 0.262 & 0.599 & 0.473 & 0.037 \\
\hline SI2 & 0.597 & 0.586 & 0.915 & 0.578 & 0.654 & 0.694 & 0.675 & 0.229 & 0.191 & 0.667 & 0.571 & 0.025 \\
\hline SI3 & 0.423 & 0.374 & 0.779 & 0.392 & 0.533 & 0.566 & 0.616 & 0.265 & 0.175 & 0.555 & 0.451 & 0.097 \\
\hline SI4 & 0.670 & 0.495 & 0.821 & 0.700 & 0.658 & 0.729 & 0.636 & 0.251 & 0.266 & 0.687 & 0.560 & -0.033 \\
\hline $\mathrm{FCl}$ & 0.706 & 0.657 & 0.604 & 0.887 & 0.782 & 0.755 & 0.559 & 0.379 & 0.181 & 0.598 & 0.720 & -0.080 \\
\hline $\mathrm{FC} 2$ & 0.413 & 0.582 & 0.465 & 0.805 & 0.565 & 0.469 & 0.522 & 0.202 & 0.152 & 0.506 & 0.608 & 0.007 \\
\hline $\mathrm{FC}_{3}$ & 0.624 & 0.638 & 0.593 & 0.907 & 0.706 & 0.658 & 0.535 & 0.314 & 0.097 & 0.571 & 0.650 & -0.010 \\
\hline $\mathrm{HMl}$ & 0.695 & 0.649 & 0.706 & 0.760 & 0.901 & 0.800 & 0.611 & 0.367 & 0.133 & 0.620 & 0.711 & -0.145 \\
\hline $\mathrm{HM} 2$ & 0.685 & 0.859 & 0.574 & 0.730 & 0.904 & 0.696 & 0.639 & 0.360 & 0.084 & 0.520 & 0.725 & -0.118 \\
\hline HMB & 0.749 & 0.785 & 0.622 & 0.672 & 0.920 & 0.738 & 0.626 & 0.357 & 0.224 & 0.552 & 0.773 & -0.111 \\
\hline PV1 & 0.663 & 0.775 & 0.604 & 0.645 & 0.803 & 0.841 & 0.605 & 0.407 & 0.104 & 0.557 & 0.643 & -0.107 \\
\hline PV2 & 0.689 & 0.518 & 0.794 & 0.641 & 0.685 & 0.936 & 0.697 & 0.329 & 0.317 & 0.778 & 0.615 & -0.020 \\
\hline PV3 & 0.724 & 0.669 & 0.694 & 0.715 & 0.783 & 0.942 & 0.622 & 0.454 & 0.246 & 0.651 & 0.692 & -0.035 \\
\hline HAl & 0.524 & 0.560 & 0.658 & 0.647 & 0.685 & 0.655 & 0.911 & 0.322 & 0.265 & 0.741 & 0.749 & 0.056 \\
\hline $\mathrm{HA} 2$ & 0.534 & 0.547 & 0.668 & 0.567 & 0.647 & 0.640 & 0.938 & 0.263 & 0.217 & 0.753 & 0.650 & 0.035 \\
\hline HA 3 & 0.491 & 0.480 & 0.704 & 0.506 & 0.573 & 0.674 & 0.925 & 0.210 & 0.250 & 0.839 & 0.558 & 0.028 \\
\hline PRVR2 & 0.256 & 0.302 & 0.309 & 0.349 & 0.398 & 0.430 & 0.288 & 1.000 & 0.581 & 0.246 & 0.455 & -0.088 \\
\hline SECR1 & 0.174 & 0.226 & 0.207 & 0.138 & 0.198 & 0.178 & 0.211 & 0.464 & 0.839 & 0.198 & 0.225 & -0.119 \\
\hline SECR 3 & 0.118 & -0.004 & 0.257 & 0.154 & 0.107 & 0.264 & 0.252 & 0.553 & 0.924 & 0.345 & 0.242 & 0.068 \\
\hline BI1 & 0.536 & 0.419 & 0.724 & 0.610 & 0.570 & 0.705 & 0.798 & 0.312 & 0.341 & 0.932 & 0.630 & 0.023 \\
\hline $\mathrm{BI} 2$ & 0.453 & 0.417 & 0.665 & 0.536 & 0.523 & 0.635 & 0.773 & 0.157 & 0.259 & 0.921 & 0.542 & 0.102 \\
\hline $\mathrm{BI} 3$ & 0.514 & 0.513 & 0.676 & 0.637 & 0.632 & 0.705 & 0.756 & 0.208 & 0.282 & 0.917 & 0.671 & -0.055 \\
\hline UB1 & 0.629 & 0.631 & 0.575 & 0.650 & 0.758 & 0.668 & 0.626 & 0.431 & 0.229 & 0.628 & 0.935 & -0.101 \\
\hline UB2 & 0.485 & 0.516 & 0.524 & 0.629 & 0.624 & 0.590 & 0.607 & 0.280 & 0.268 & 0.637 & 0.817 & 0.051 \\
\hline UB3 & 0.606 & 0.666 & 0.564 & 0.710 & 0.742 & 0.640 & 0.673 & 0.455 & 0.232 & 0.607 & 0.956 & -0.092 \\
\hline UB4 & 0.641 & 0.733 & 0.546 & 0.752 & 0.786 & 0.663 & 0.641 & 0.460 & 0.230 & 0.546 & 0.892 & -0.110 \\
\hline GENDER & -0.089 & -0.121 & 0.033 & -0.035 & -0.139 & -0.054 & 0.043 & -0.088 & -0.011 & 0.023 & -0.075 & 1.000 \\
\hline
\end{tabular}

(Sumber: Hasil Pengolahan SmartPLS 3.2.9, 2020)

Nilai masing-masing indikator yang ada disuatu konstruk memiliki perbedaan dengan indikator di konstruk lain. Hal tersebut ditunjukkan dengan nilai loading yang berada pada kolom berwarna kuning memiliki nilai yang lebih tinggi daripada indikator di konstruk lainnya. Dengan demikian, nilai cross loading seluruh indikator telah memenuhi syarat uji validitas diskriminan. Begitu pula pada aplikasi $\mathrm{m}$ commerce lazada, tokopedia, bukalapak, dan blibli. Semua indikatornya telah memenuhi syarat uji validitas diskriminan. 


\subsubsection{Uji Reliabilitas}

Pengujian reliabilitas dilakukan dengan melihat nilai dari cronbach's alpha dan composite reliability. Tujuan dari pengujian reliabilitas adalah untuk mengukur konsistensi internal alat ukur dalam sebuah penelitian. Nilai cronbach's alpha dikatakan reliable jika memenuhi rule of thumb $>0,6$ dan composite reliability dikatakan reliable jika memenuhi rule of thumb $>0,7[10]$. Masing-masing nilai cronbach's Alpha dan composite Reliability sudah memenuhi rule of thumb, dapat dilihat pada Tabel 5.

Tabel 5. Nilai Cronbach's Alpha dan Composite Reliability

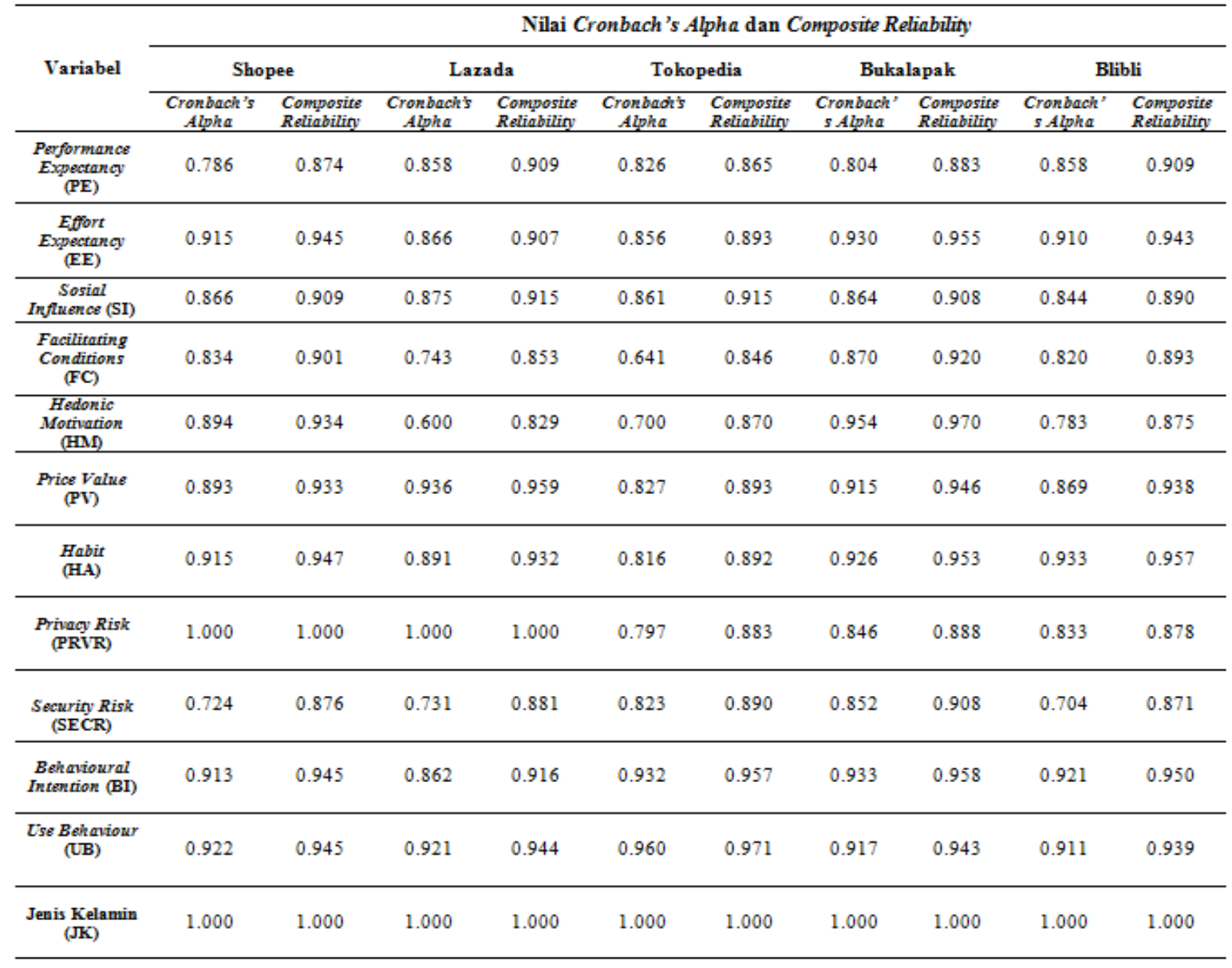

(Sumber: Hasil Pengolahan SmartPLS 3.2.9, 2020)

\subsection{Pengujian Model Struktural (Inner Model)}

Pengujian model struktural dievaluasi menggunakan Coefficient of Determinant $\left(\mathrm{R}^{2}\right)$ untuk konstruk dependen dan nilai koefisien path atau t-value tiap path untuk pengujian hipotesis. Tabel 6. merupakan nilai $\mathrm{R}$-Square $\left(\mathrm{R}^{2}\right)$ dari masing-masing $m$-commerce.

Tabel 6. Nilai R-Square $\left(\mathrm{R}^{2}\right)$

\begin{tabular}{cccccc}
\hline \multirow{2}{*}{ Variabel } & \multicolumn{5}{c}{ Nilai R-Square $\left(\mathbf{R}^{2}\right)$} \\
\cline { 2 - 5 } & Shopee & Lazada & Tokopedia & Bukalapak & Blibli \\
\hline $\begin{array}{c}\text { Behavioural } \\
\text { Intention (BI) }\end{array}$ & 0.805 & 0.915 & 0.809 & 0.801 & 0.843 \\
\hline $\begin{array}{c}\text { Use Behaviour } \\
\text { (UB) }\end{array}$ & 0.705 & 0.801 & 0.449 & 0.711 & 0.845
\end{tabular}

(Sumber: Hasil Pengolahan SmartPLS 3.2.9, 2020) 
Pada aplikasi Shopee, nilai $\mathrm{R}^{2}$ untuk variabel Behaviour Intention (BI) sebesar 0.805. Hal ini menunjukkan bahwa, pengaruh PE, EE, SI, FC, HM, PV, HA, SECR, dan PRVR terhadap BI sebesar 0.805 atau 80,5 persen. Untuk variabel Use Behaviour (UB), pengaruhnya sebesar 0.705. Hal ini menunjukkan bahwa, pengaruh FC, HA, SECR, PRVR, dan BI terhadap UB sebesar 0.705 atau 70,5 persen. Pada aplikasi Lazada, nilai $\mathrm{R}^{2}$ untuk variabel Behaviour Intention (BI) sebesar 0.915. Hal ini menunjukkan bahwa, pengaruh PE, EE, SI, FC, HM, PV, HA, SECR, dan PRVR terhadap BI sebesar 0.915 atau 91,5 persen. Untuk variabel Use Behaviour (UB), pengaruhnya sebesar 0.801. Hal ini menunjukkan bahwa, pengaruh FC, HA, SECR, PRVR, dan BI terhadap UB sebesar 0.801 atau 80,1 persen. Pada aplikasi Tokopedia, nilai $\mathrm{R}^{2}$ untuk variabel Behaviour Intention (BI) sebesar 0.809. Hal ini menunjukkan bahwa, pengaruh PE, EE, SI, FC, HM, PV, HA, SECR, dan PRVR terhadap BI sebesar 0.809 atau 80,9 persen. Untuk variabel Use Behaviour (UB), pengaruhnya sebesar 0.449. Hal ini menunjukkan bahwa, pengaruh FC, HA, SECR, PRVR, dan BI terhadap UB sebesar 0.449 atau 44,9 persen. Pada aplikasi Bukalapak, nilai $\mathrm{R}^{2}$ untuk variabel Behaviour Intention (BI) sebesar 0.801. Hal ini menunjukkan bahwa, pengaruh PE, EE, SI, FC, HM, PV, HA, SECR, dan PRVR terhadap BI sebesar 0.801 atau 80,1 persen. Untuk variabel Use Behaviour (UB), pengaruhnya sebesar 0.711 . Hal ini menunjukkan bahwa, pengaruh FC, HA, SECR, PRVR, dan BI terhadap UB sebesar 0.711 atau 71,1 persen. Pada aplikasi Blibli, nilai $\mathrm{R}^{2}$ untuk variabel Behaviour Intention (BI) sebesar 0.843. Hal ini menunjukkan bahwa, pengaruh variabel PE, EE, SI, FC, HM, PV, HA, SECR, dan PRVR terhadap BI sebesar 0.843 atau 84,3 persen. Untuk variabel Use Behaviour (UB), pengaruhnya sebesar 0.845. Hal ini menunjukkan bahwa, pengaruh FC, HA, SECR, PRVR, dan BI terhadap UB sebesar 0.845 atau 84,5 persen variabel UB. Secara keseluruhan, nilai $\mathrm{R}^{2}$ yang diperoleh dikatakan baik karena memiliki nilai lebih dari 0 . Nilai $\mathrm{R}^{2}$ yang baik yaitu antara 0 sampai 1 . Semakin mendekati angka 1 semakin baik.

Langkah selanjutnya, melakukan proses bootstrapping. Proses bootstrapping menghasilkan nilai koefisien jalur dan T-statistic untuk pengujian hipotesis. Lalu, jumlah samples yang diiterasi dalam SmartPLS 3.2.9 sebanyak 500 (default) supaya mendapatkan nilai T-statistic yang stabil. Bootstrapping di penelitian ini menggunakan test type Two Tailed (pengujian hipotesis dua ekor) dengan significance level 0.05. Hasil boostrapping yang signifikan (T-statistic lebih dari 1,96) pada penelitian ini adalah sebagai berikut.

1. Shopee : FC terhadap BI, FC terhadap UB, PV terhadap BI, HA terhadap BI, HA terhadap UB, PRVR terhadap BI, PRVR terhadap UB, dan SECR terhadap BI.

2. Lazada : SI terhadap BI, HA terhadap UB, dan BI terhadap UB.

3. Tokopedia : HA terhadap BI dan HA terhadap UB.

4. Bukalapak : FC terhadap UB, HA terhadap BI, dan HA terhadap UB.

5. Blibli : FC terhadap BI, FC terhadap UB, HA terhadap UB, dan JK terhadap UB.

\subsection{Pengujian Hipotesis}

Jika nilai T-statistic $>\mathrm{T}$-table, maka $\mathrm{H}_{0}$ ditolak. Jika nilai $\mathrm{T}$-statistic $<\mathrm{T}$-table, maka $\mathrm{H}_{0}$ diterima. Pengujian dilakukan dengan membandingkan T-statistic hasil boostrapping dengan T-table. Acuan nilai T-table yang digunakan untuk pengujian hipotesis penelitian ini adalah hipotesis dua ekor (two-tailed) yaitu 1,96. Tingkat signifikansi pada path coefficients mengunakan $95 \%(\alpha=0.05)$. Pada penelitian ini, variabel-variabel yang memiliki hubungan adalah sebagai berikut.

Pada aplikasi shopee, variabel yang memiliki hubungan adalah sebagai berikut :

1. Hubungan kondisi-kondisi pemfasilitasi (facilitating conditions) dengan niat perilaku (behavioural intention).

- $\mathrm{H}_{0}$ : Tidak ada hubungan antara kondisi-kondisi pemfasilitasi (facilitating conditions) dengan niat perilaku (behavioural intention).

- $\mathrm{H}_{4 \mathrm{a}}$ : Terdapat hubungan antara kondisi-kondisi pemfasilitasi (facilitating conditions) dengan niat perilaku (behavioural intention).

Arah hubungan kondisi-kondisi pemfasilitasi (facilitating conditions) terhadap niat perilaku (behavioural intention) bersifat positif dengan nilai original sample adalah positif yaitu sebesar 0.229. Variabel FC terhadap variabel BI menghasilkan T-statistic sebesar 2.881. Nilai T-statistic lebih besar dari T-table. 
Dapat dikatakan bahwa hipotesis $\mathrm{H}_{0}$ ditolak, yang berarti ada hubungan yang signifikan antara kondisikondisi pemfasilitasi (facilitating conditions) dengan niat perilaku (behavioural intention).

2. Hubungan kondisi-kondisi pemfasilitasi (facilitating conditions) dengan perilaku penggunaan (use behaviour).

- $\mathrm{H}_{0}$ : Tidak ada hubungan antara kondisi-kondisi pemfasilitasi (facilitating conditions) dengan perilaku penggunaan (use behaviour).

- $\mathrm{H}_{4 \mathrm{~b}}$ : Terdapat hubungan antara kondisi-kondisi pemfasilitasi (facilitating conditions) dengan perilaku penggunaan (use behaviour).

Arah hubungan kondisi-kondisi pemfasilitasi (facilitating conditions) terhadap perilaku penggunaan (use behaviour) bersifat positif dengan nilai original sample adalah positif yaitu sebesar 0.451. Variabel FC terhadap variabel UB menghasilkan T-statistic sebesar 6.242. Nilai T-statistic lebih besar dari T-table. Dapat dikatakan bahwa hipotesis $\mathrm{H}_{0}$ ditolak, yang berarti ada hubungan yang signifikan antara kondisikondisi pemfasilitasi (facilitating conditions) dengan perilaku penggunaan (use behaviour).

3. Hubungan nilai harga (price value) dengan niat perilaku (behavioural intention).

- $\mathrm{H}_{0}$ : Tidak ada hubungan antara nilai harga (price value) dengan niat perilaku (behavioural intention).

- $\mathrm{H}_{6}$ : Terdapat hubungan antara nilai harga (price value) dengan niat perilaku (behavioural intention).

Arah hubungan nilai harga (price value) terhadap niat perilaku (behavioural intention) bersifat positif dengan nilai original sample adalah positif yaitu sebesar 0.346. Variabel PV terhadap variabel BI

menghasilkan T-statistic sebesar 3.275. Nilai T-statistic lebih besar dari T-table. Dapat dikatakan bahwa hipotesis $\mathrm{H}_{0}$ ditolak, yang berarti ada hubungan yang signifikan antara nilai harga (price value) terhadap niat perilaku (behavioural intention).

4. Hubungan kebiasaan (habit) dengan niat perilaku (behavioural intention).

- $\mathrm{H}_{0}$ : Tidak ada hubungan antara kebiasaan (habit) dengan niat perilaku (behavioural intention)

- $\mathrm{H}_{7 \mathrm{a}}$ : Terdapat hubungan antara kebiasaan (habit) dengan niat perilaku (behavioural intention).

Arah hubungan kebiasaan (habit) terhadap niat perilaku (behavioural intention) bersifat positif dengan nilai original sample adalah positif yaitu sebesar 0.562. Variabel HA terhadap variabel BI menghasilkan T-statistic sebesar 8.261. Nilai T-statistic lebih besar dari T-table. Dapat dikatakan bahwa hipotesis $\mathrm{H}_{0}$ ditolak, yang berarti ada hubungan yang signifikan antara kebiasaan (habit) terhadap niat perilaku (behavioural intention).

5. Hubungan kebiasaan (habit) dengan perilaku penggunaan (use behaviour).

- $\mathrm{H}_{0}$ : Tidak ada hubungan antara kebiasaan (habit) dengan perilaku penggunaan (use behaviour)

- $\mathrm{H}_{7 \mathrm{~b}}$ : Terdapat hubungan antara kebiasaan (habit) dengan perilaku penggunaan (use behaviour).

Arah hubungan kebiasaan (habit) terhadap perilaku penggunaan (use behaviour) bersifat positif dengan nilai original sample adalah positif yaitu sebesar 0.324 . Variabel HA terhadap variabel UB menghasilkan T-statistic sebesar 3.014. Nilai T-statistic lebih besar dari T-table. Dapat dikatakan bahwa hipotesis $\mathrm{H}_{0}$ ditolak, yang berarti ada hubungan yang signifikan antara kebiasaan (habit) terhadap perilaku penggunaan (use behaviour).

6. Hubungan resiko privasi (privacy risk) dengan niat perilaku (behavioural intention).

- $\mathrm{H}_{0}$ : Tidak ada hubungan antara resiko privasi (privacy risk) dengan niat perilaku (behavioural intention).

- $\mathrm{H}_{9 \mathrm{a}}$ : Terdapat hubungan antara resiko privasi (privacy risk) dengan niat perilaku (behavioural intention).

Arah hubungan resiko privasi (privacy risk) terhadap niat perilaku (behavioural intention) bersifat negatif dengan nilai original sample adalah negatif yaitu sebesar -0.170 . Variabel PRVR terhadap variabel BI menghasilkan T-statistic sebesar 2.256. Nilai T-statistic lebih besar dari T-table. Dapat dikatakan bahwa hipotesis $\mathrm{H}_{0}$ ditolak, yang berarti ada hubungan yang signifikan antara resiko privasi (privacy risk) terhadap niat perilaku (behavioural intention).

7. Hubungan resiko privasi (privacy risk) dengan perilaku penggunaan (use behaviour). 
- $\mathrm{H}_{0}$ : Tidak ada hubungan antara resiko privasi (privacy risk) dengan perilaku penggunaan (use behaviour).

- $\mathrm{H}_{9 \mathrm{~b}}$ : Terdapat hubungan antara resiko privasi (privacy risk) dengan perilaku penggunaan (use behaviour).

Arah hubungan resiko privasi (privacy risk) terhadap perilaku penggunaan (use behaviour) bersifat positif dengan nilai original sample adalah positif yaitu sebesar 0.205. Variabel PRVR terhadap variabel UB menghasilkan T-statistic sebesar 2.011. Nilai T-statistic lebih besar dari T-table. Dapat dikatakan bahwa hipotesis $\mathrm{H}_{0}$ ditolak, yang berarti ada hubungan yang signifikan antara resiko privasi (privacy risk) terhadap perilaku penggunaan (use behaviour).

8. Hubungan resiko keamanan (security risk) dengan niat perilaku (behavioural intention).

- $\mathrm{H}_{0}$ : Tidak ada hubungan antara resiko keamanan (security risk) dengan niat perilaku (behavioural intention).

- $\mathrm{H}_{10 \mathrm{a}}$ : Terdapat hubungan antara resiko keamanan (security risk) dengan niat perilaku (behavioural intention).

Arah hubungan resiko keamanan (security risk) terhadap niat perilaku (behavioural intention) bersifat positif dengan nilai original sample adalah positif yaitu sebesar 0.151. Variabel SECR terhadap variabel BI menghasilkan T-statistic sebesar 2.088. Nilai T-statistic lebih besar dari T-table. Dapat dikatakan bahwa hipotesis $\mathrm{H}_{0}$ ditolak, yang berarti ada hubungan yang signifikan antara resiko keamanan (security risk) terhadap niat perilaku (behavioural intention).

Pada aplikasi lazada, variabel yang memiliki hubungan adalah sebagai berikut :

1. Hubungan pengaruh sosial (sosial influence) dengan niat perilaku (behavioural intention).

- $\mathrm{H}_{0}$ : Tidak ada hubungan antara pengaruh sosial (sosial influence) dengan niat perilaku (behavioural intention).

- $\mathrm{H}_{3}$ : Terdapat hubungan antara pengaruh sosial (sosial influence) dengan niat perilaku (behavioural intention).

Arah hubungan pengaruh sosial (sosial influence) terhadap niat perilaku (behavioural intention) bersifat positif dengan nilai original sample adalah positif yaitu sebesar 1.095. Variabel SI terhadap variabel BI menghasilkan T-statistic sebesar 2.666. Nilai T-statistic lebih besar dari T-table. Dapat dikatakan bahwa hipotesis $\mathrm{H}_{0}$ ditolak, yang berarti ada hubungan yang signifikan antara pengaruh sosial (sosial influence) dengan niat perilaku (behavioural intention).

2. Hubungan kebiasaan (habit) dengan niat perilaku (behavioural intention).

- $\mathrm{H}_{0}$ : Tidak ada hubungan antara kebiasaan (habit) dengan niat perilaku (behavioural intention)

- $\quad \mathrm{H}_{7 \mathrm{a}}$ : Terdapat hubungan antara kebiasaan (habit) dengan niat perilaku (behavioural intention).

Arah hubungan kebiasaan (habit) terhadap niat perilaku (behavioural intention) bersifat positif dengan nilai original sample adalah positif yaitu sebesar 0.593. Variabel HA terhadap variabel BI menghasilkan T-statistic sebesar 2.840. Nilai T-statistic lebih besar dari T-table. Dapat dikatakan bahwa hipotesis $\mathrm{H}_{0}$ ditolak, yang berarti ada hubungan yang signifikan antara kebiasaan (habit) terhadap niat perilaku (behavioural intention).

3. Hubungan niat perilaku (behavioural intention) dengan perilaku penggunaan (use behaviour).

- $\mathrm{H}_{0}$ : Tidak ada hubungan antara niat perilaku (behavioural intention) dengan perilaku penggunaan (use behaviour).

- $\mathrm{H}_{8}$ : Terdapat hubungan antara niat perilaku (behavioural intention) dengan perilaku penggunaan (use behaviour).

Arah hubungan niat perilaku (behavioural intention) terhadap perilaku penggunaan (use behaviour) bersifat positif dengan nilai original sample adalah positif yaitu sebesar 0.768 . Variabel BI terhadap variabel UB menghasilkan T-statistic sebesar 3.488. Nilai T-statistic lebih besar dari T-table. Dapat dikatakan bahwa hipotesis $\mathrm{H}_{0}$ ditolak, yang berarti ada hubungan yang signifikan antara niat perilaku (behavioural intention) terhadap perilaku penggunaan (use behaviour).

Pada aplikasi tokopedia, variabel yang memiliki hubungan adalah sebagai berikut : 
1. Hubungan kebiasaan (habit) dengan niat perilaku (behavioural intention).

- $\mathrm{H}_{0}$ : Tidak ada hubungan antara kebiasaan (habit) dengan niat perilaku (behavioural intention)

- $\quad \mathrm{H}_{7 \mathrm{a}}$ : Terdapat hubungan antara kebiasaan (habit) dengan niat perilaku (behavioural intention).

Arah hubungan kebiasaan (habit) terhadap niat perilaku (behavioural intention) bersifat positif dengan nilai original sample adalah positif yaitu sebesar 0.907. Variabel HA terhadap variabel BI menghasilkan T-statistic sebesar 5.720. Nilai T-statistic lebih besar dari T-table. Dapat dikatakan bahwa hipotesis $\mathrm{H}_{0}$ ditolak, yang berarti ada hubungan yang signifikan antara kebiasaan (habit) terhadap niat perilaku (behavioural intention).

2. Hubungan kebiasaan (habit) dengan perilaku penggunaan (use behaviour).

- $\mathrm{H}_{0}$ : Tidak ada hubungan antara nilai harga (price value) dengan perilaku penggunaan (use behaviour).

- $\mathrm{H}_{7 \mathrm{~b}}$ : Terdapat hubungan antara nilai harga (price value) dengan perilaku penggunaan (use behaviour). Arah hubungan kebiasaan (habit) terhadap perilaku penggunaan (use behaviour) bersifat positif dengan nilai original sample adalah positif yaitu sebesar 0.838 . Variabel HA terhadap variabel UB menghasilkan T-statistic sebesar 3.302. Nilai T-statistic lebih besar dari T-table. Dapat dikatakan bahwa hipotesis $\mathrm{H}_{0}$ ditolak, yang berarti ada hubungan yang signifikan antara kebiasaan (habit) terhadap perilaku penggunaan (use behaviour).

Pada aplikasi bukalapak, variabel yang memiliki hubungan adalah sebagai berikut :

1. Hubungan kondisi-kondisi pemfasilitasi (facilitating conditions) dengan perilaku penggunaan (use behaviour).

- $\mathrm{H}_{0}$ : Tidak ada hubungan antara kondisi-kondisi pemfasilitasi (facilitating conditions) dengan perilaku penggunaan (use behaviour).

- $\mathrm{H}_{4 \mathrm{~b}}$ : Terdapat hubungan antara kondisi-kondisi pemfasilitasi (facilitating conditions) dengan perilaku penggunaan (use behaviour).

Arah hubungan kondisi-kondisi pemfasilitasi (facilitating conditions) terhadap perilaku penggunaan (use behaviour) bersifat positif dengan nilai original sample adalah positif yaitu sebesar 0.524. Variabel FC terhadap variabel UB menghasilkan T-statistic sebesar 4.306. Nilai T-statistic lebih besar dari T-table. Dapat dikatakan bahwa hipotesis $\mathrm{H}_{0}$ ditolak, yang berarti ada hubungan yang signifikan antara kondisikondisi pemfasilitasi (facilitating conditions) dengan perilaku penggunaan (use behaviour).

2. Hubungan kebiasaan (habit) dengan niat perilaku (behavioural intention).

- $\mathrm{H}_{0}$ : Tidak ada hubungan antara kebiasaan (habit) dengan niat perilaku (behavioural intention)

- $\quad \mathrm{H}_{7 \mathrm{a}}$ : Terdapat hubungan antara kebiasaan (habit) dengan niat perilaku (behavioural intention).

Arah hubungan kebiasaan (habit) terhadap niat perilaku (behavioural intention) bersifat positif dengan nilai original sample adalah positif yaitu sebesar 0.675. Variabel HA terhadap variabel BI menghasilkan T-statistic sebesar 5.009. Nilai T-statistic lebih besar dari T-table. Dapat dikatakan bahwa hipotesis $\mathrm{H}_{0}$ ditolak, yang berarti ada hubungan yang signifikan antara kebiasaan (habit) terhadap niat perilaku (behavioural intention).

3. Hubungan kebiasaan (habit) dengan perilaku penggunaan (use behaviour).

- $\mathrm{H}_{0}$ : Tidak ada hubungan antara kebiasaan (habit) dengan perilaku penggunaan (use behaviour).

- $\quad \mathrm{H}_{7 \mathrm{~b}}$ : Terdapat hubungan antara kebiasaan (habit) dengan perilaku penggunaan (use behaviour).

Arah hubungan kebiasaan (habit) terhadap perilaku penggunaan (use behaviour) bersifat positif dengan nilai original sample adalah positif yaitu sebesar 0.279 . Variabel HA terhadap variabel UB menghasilkan T-statistic sebesar 1.709. Nilai T-statistic lebih besar dari T-table. Dapat dikatakan bahwa hipotesis $\mathrm{H}_{0}$ ditolak, yang berarti ada hubungan yang signifikan antara kebiasaan (habit) terhadap perilaku penggunaan (use behaviour).

Pada aplikasi blibli, variabel yang memiliki hubungan adalah sebagai berikut :

1. Hubungan kondisi-kondisi pemfasilitasi (facilitating conditions) dengan niat perilaku (behavioural intention).

- $\mathrm{H}_{0}$ : Tidak ada hubungan antara kondisi-kondisi pemfasilitasi (facilitating conditions) dengan niat perilaku (behavioural intention). 
- $\mathrm{H}_{4 \mathrm{a}}$ : Terdapat hubungan antara kondisi-kondisi pemfasilitasi (facilitating conditions) dengan niat perilaku (behavioural intention).

Arah hubungan kondisi-kondisi pemfasilitasi (facilitating conditions) terhadap niat perilaku (behavioural intention) bersifat positif dengan nilai original sample adalah positif yaitu sebesar 0.370 . Variabel FC terhadap variabel BI menghasilkan T-statistic sebesar 2.274. Nilai T-statistic lebih besar dari T-table. Dapat dikatakan bahwa hipotesis $\mathrm{H}_{0}$ ditolak, yang berarti ada hubungan yang signifikan antara kondisikondisi pemfasilitasi (facilitating conditions) dengan niat perilaku (behavioural intention).

2. Hubungan kondisi-kondisi pemfasilitasi (facilitating conditions) dengan perilaku penggunaan (use behaviour).

- $\mathrm{H}_{0}$ : Tidak ada hubungan antara kondisi-kondisi pemfasilitasi (facilitating conditions) dengan perilaku penggunaan (use behaviour).

- $\mathrm{H}_{4 \mathrm{~b}}$ : Terdapat hubungan antara kondisi-kondisi pemfasilitasi (facilitating conditions) dengan perilaku penggunaan (use behaviour).

Arah hubungan kondisi-kondisi pemfasilitasi (facilitating conditions) terhadap perilaku penggunaan (use behaviour) bersifat positif dengan nilai original sample adalah positif yaitu sebesar 0.307. Variabel FC terhadap variabel UB menghasilkan T-statistic sebesar 2.206. Nilai T-statistic lebih besar dari T-table. Dapat dikatakan bahwa hipotesis $\mathrm{H}_{0}$ ditolak, yang berarti ada hubungan yang signifikan antara kondisikondisi pemfasilitasi (facilitating conditions) dengan perilaku penggunaan (use behaviour).

3. Hubungan kebiasaan (habit) dengan perilaku penggunaan (use behaviour).

- $\mathrm{H}_{0}$ : Tidak ada hubungan antara kebiasaan (habit) dengan perilaku penggunaan (use behaviour).

- $\mathrm{H}_{7 \mathrm{~b}}$ : Terdapat hubungan antara kebiasaan (habit) dengan perilaku penggunaan (use behaviour).

Arah hubungan kebiasaan (habit) terhadap perilaku penggunaan (use behaviour) bersifat positif dengan nilai original sample adalah positif yaitu sebesar 0.371. Variabel HA terhadap variabel UB menghasilkan T-statistic sebesar 2.393. Nilai T-statistic lebih besar dari T-table. Dapat dikatakan bahwa hipotesis $\mathrm{H}_{0}$ ditolak, yang berarti ada hubungan yang signifikan antara kebiasaan (habit) terhadap perilaku penggunaan (use behaviour).

4. Hubungan resiko jenis kelamin (gender) dengan perilaku penggunaan (use behaviour).

- $\mathrm{H}_{0}$ : Tidak ada hubungan antara jenis kelamin (gender) dengan perilaku penggunaan (use behaviour).

- $\mathrm{H}_{1 \mathrm{~b}}$ : Terdapat hubungan antara jenis kelamin (gender) dengan perilaku penggunaan (use behaviour).

Arah hubungan jenis kelamin (gender) dengan perilaku penggunaan (use behaviour) bersifat negatif dengan nilai original sample adalah negatif yaitu sebesar -0.211 . Variabel JK terhadap variabel UB menghasilkan T-statistic sebesar 2.138. Nilai T-statistic lebih besar dari T-table. Dapat dikatakan bahwa hipotesis $\mathrm{H}_{0}$ ditolak, yang berarti ada hubungan yang signifikan antara jenis kelamin (gender) terhadap perilaku penggunaan (use behaviour).

\section{KESIMPULAN}

Berdasarkan hasil penelitian yang telah dilakukan, maka dapat disimpulkan bahwa habit terhadap Behavioural Intention dan Habit terhadap Use Behaviour berpengaruh positif dan signifikan pada penggunaan aplikasi Shopee, Lazada, Tokopedia, Bukalapak, dan Blibli. Privacy Risk terhadap Behavioural Intention berpengaruh negatif dan signifikan pada penggunaan aplikasi shopee, Privacy Risk terhadap Use Behaviour berpengaruh positif dan signifikan pada penggunaan aplikasi shopee, dan Security Risk terhadap Behavioural Intention berpengaruh positif dan signifikan pada penggunaan aplikasi shopee.

\section{DAFTAR PUSTAKA}

[1] Hidayat, T. 2008. Panduan Membuat Toko Online dengan OSCommerce. Mediakita.Jakarta. 
[2] Irmawati, Dewi. 2011. Pemanfaatan E-Commerce Dalam Dunia Bisnis. Jurnal Ilmiah Orasi Bisnis. Edisi Ke-VI. Politeknik Negeri Sriwijaya.

[3] Dewi, Ni Made A. P dan Warmika, I Gede Kt. 2016. Peran Persepsi Kemudahan Penggunan, Persepsi Manfaat Dan Perspsi Resiko Terhadap Niat Menggunakan Mobile Commerce Di Kota Denpasar. EJurnal Manajemen Unud. Vol. 5, No. 4.

[4] APJII. 2018. Penetrasi \& Profil Perilaku Pengguna Internet Indonesia. https://www.apjii.or.id/survei2017 (Diakses pada tanggal 23 Januari 2020).

[5] APJII. 2017. Infografis Penetrasi dan Perilaku Pengguna Internet Indonesia. https://www.apjii.or.id/survei2017 (Diakses pada tanggal 23 Desember 2019).

[6] APJII. 2016. Penetrasi \& Perilaku Pengguna Internet Indonesia. https://www.apjii.or.id/survei2016, (Diakses pada tanggal 23 Desember 2019).

[7] iPrice Insights. 2019. Peta E-Commerce Indonesia. https://iprice.co.id/insights/mapofecommerce/ (Diakses pada tanggal 30 Desember 2019).

[8] Venkatesh, V., Thong, J. Y., \& Xu, X. 2012. Consumer acceptance and use of information technology: extending the unified theory of acceptance and use of technology. Management Information System Quarterly, 36(1), 157-178.

[9] Korfiatis, N., Chopdar, Prasanta Kr., Sivakumar, V.J., \& Lytras, Miltiades D. 2018. Mobile shopping apps adoption and perceived risks: A cross-country perspective utilizing the Unified Theory of Acceptance and Use of Technology. Computer in Human Behavior. Vol. 86, Pages 109-128.

[10] Jogiyanto dan Abdillah, W. 2016. Konsep dan Aplikasi PLS (Partial Least Square) Untuk Penelitian Empiris. BPFE-Yogyakarta. Yogyakarta. 